\title{
PRIVATE FOUNDATIONS IN THE UNITED STATES
}

$I^{\mathrm{N}}$ NFORMATION on rosearch and other activities of 272 private philanthropic foundations gleaned from a survey conducted by the U.S. National Science Foundation in 1960 is summarized in a report issued by the Foundation*

Research funds accounted for 20 per cent of the total expenditure of 437 million dollars for all activities of these foundations, and of the remainder 72 million dollars represented funds for medical research or research rolated to health and education, of which 47 million dollars was for research and 25 million dollars for education. Eightynine million dollars of the total research expenditure came from 177 of these foundations and of this 85 per cent was for curront operating expenses and 14 per cont for new capital experditure. Soventy-six million dollars went to research carried out by the foundations' personnel in the United States and abroad, and almost 15 million dollars was spent on intramural research. All but 12.5 million dollars of the extramural expenditure was spent within the United States, and of the 62 million dollars so spent 35 million went to colleges and universities, 11 million dollars to hospitals and 8 million dollars to independent non-profit research institutes.

More than half the 76 million dollars spent on resoarch by the 177 private foundations went on basic research projects, the total in 1960 reaching 42 million dollars, of * National Science Foundation, Washington. NSF 64-14: Research and other Activities of Private Foundations, 1960. (Surveys of Science Research Series.) Pp. xi + 33. (Washington, D.C.: Government Printing Office, 1964.) which 8 million dollars represented funds for basic research by individuals and 34 million dollars for projects conducted in outside organizations. Of the total, 22 millions were spont on the life sciences, 10 millions on the social sciences, 6 millions on the physical sciences, and 2 million dollars on psychology. Three-quarters of basic research funds for the lifo and physical scionces were used extramurally. The financial support of applied research by private foundations totalled 34 million dollars, and four-fifths of this was allocated to the social and lifo sciences.

In January 1961,59 of the 272 foundations replying reported employment of 758 scientists and enginoers, and of this number 650 were working full-time including 441 scientists and engineers engaged on research.

The four foundations with the largest research programmes accounted for 52 per cent of the total research expenditure. Out of the 177 private foundations twelve spent more than 1 million dollars on research in 1963. These accounted for 63 million dollars of the total. Intramural research amounted to almost 10 million dollars and extramural research to 53 million dollars, or 71 per cent of the total funds spent by all the foundations surveyed.

Research grants going to educational institutions from the twelve foundations spending more than 1 million dollars amounted to 24 million dollars, or more than twothirds of the total of research funds from this source, while 28 million dollars (three-quarters of the total) went to hospitals, and 4 million dollars to independent nonprofit research institutions.

\section{WOOL SCOURING}

T HE large international attendance at a colloquium on "Wool Scouring", held at the Commonwealth Scientific and Industrial Research Organization Division of Textile Industry, Geelong, Australia, on October 26, was indicative of the growing scientific interest in this traditional process. Participants included representatives from industry, universities and technical colleges, research organizations, the Australian Wool Board, and the International Wool Secretariat.

In his opening paper on "The Importance of Scouring", Dr. M. Lipson, chief of the Division, gave a broad survey of the requirements of good scouring. From a consideration of the contaminants present on the floece, he went on to discuss the various methods of removing them, and some of the effects of these methods on the subsequent behaviour of the wool in processing. Ho deprecated the still-common attitude of merchants who demand a conventional appearance rather than a good processing performance from the wool they buy, but forecast that this would disappoar as the industry took more account of scientific advances in processing.

Mr. W. W. Mansfield's talk on "The Fundamentals of the Detergent Process" covered the behaviour of surfaceactive materials in solution, adsorption at interfaces, the removal of solid and liquid contaminants from surfaces, and the bohaviour of charged particles in an emulsion. He emphasized the importance of a kinetic approach to detergeney problems, particularly in industrial problems where conditions are far removed from the ideal conditions of classical surface chemistry.

Recent research on scouring at C.S.I.R.O. was described by Dr. G. F. Wood. The first part of his talk covered the development of the detergent-jet scouring process, and presented the results of investigations into the effects of various factors on scouring efficiency. In the second part, he described anomalies in the behaviour of certain nonionic detergent solutions when used for scouring wool by the jet method. Differences in the ease of removal of oxidized and unoxidized wool wax from the fibre did not explain the anomalies, and it was suggested that they might be due to surface phenomena at the air/liquid interface of the jets.

In the final paper of the morning session, Prof. M. Chaikin made a statement on the present-day position of the "Compression Jet Scouring" process, which has developed from work carried out at the University of New South Wales.

Mr. P. H. A. Strasser outlined the history of synthetic detergents in relation to the textile industry and described the manufacture of non-ionic detergents. He discussed the changes that are taking place in the detergent industry, and showed how the demand for biodegradability was affecting the raw materials used for both anionic and non-ionic detergents.

There followed a critical appraisal by Mr. L. E. Way of the present situation in the scouring industry. He dis. cussed quality requirements and cost limitations in rolation to possible improvements resulting from chemical and mechanical modifications, and pointed out that quality control was hampered in some cases by lack of suitable measuring and control instruments.

The final paper, from Dr. C. A. Anderson, reviewed the present position in recovery of wool grease and offluent disposal. Dr. Anderson described the structure of wool scour liquors, and showed how various factors affected the centrifugal recovery of wool grease. He presented ostimates of the capital and operating costs of the available effuent treatment processes, and concluded that solvent 
scouring (which does not produce a noxious effluent) is the most attractive to mills where this scouring method is acceptable.

The sessions were admirably chaired by Dr. E. G. Carter and Dr. G. Laxer of the International Wool Secretariat, Mr. W. A. May of the Australian Wool Scourers' Association and Dr. F. G. Lennox of the
C.S.I.R.O. Division of Protein Chemistry. The papers were followed by lively discussion, which contributed considerably to the success of the colloquium.

The lectures will be published in full in the next few issues of the Textile Journal of Australia.

C. A. Anderson

G. F. WOOD

\section{HIGH-TEMPERATURE DYEING}

\begin{abstract}
A HALF-DAY conference on "Continuous High-temperature Dyeing" was held at the Shirley Institute, Didsbury, Manchester, on November 18. The conference consisted of two lectures given by staff from the Institute, each followed by an interval for discussion. In a joint paper, entitled "The Principles and Scope of Continuous High-temperature Dyeing", Mrs. B. J. Bonwitt and Mr. M. G. Corless dealt with the technical requiremonts of the process and the range of fibres and dyestuffs to which the technique is applicable. The differences between American and European practice were described. Whereas in America processing speeds are usually of the order of at least $100 \mathrm{yd} / \mathrm{min}$, in Europe it is uncommon for speeds to exceed $30 \mathrm{yd} / \mathrm{min}$. The difference in approach can be ascribed to the difference between the structures of the two industries. Rather surprisingly it appears that machinery designed to run at lower speeds has to be somewhat more refined than that designed for high-speed operation.

In the second paper, entitled "Modern Continuous Dyeing Machinery", Mr. L. J. Gibson reviewed the machinery at present available from Continental machinery makers and then went on to discuss economic factors. 'Thermosol' and pressure steam ranges are not economical for short runs. In general 4,000-5,000 yd. must be
\end{abstract}

regarded as the minimum length at one shade; runs in the United States are commonly of the order of $20,000 \mathrm{yd}$., and $10,000 \mathrm{yd}$. is regarded as a minimum.

'Thermosol' machinery is being used primarily for the dyeing of polyester/cotton blends; padding systems are not yet sufficiently well developed to deal with the majority of continuous filament synthetic fabrics. Pressure steam ranges are only just coming into use and are primarily used for continuous filament viscose rayon fabrics. However, they show considerable promise for the dyeing of woven nylon fabrics. It seems certain that a major reorganization of the merchanting system will have to take place before continuous high-temperature dyeing can be exploited to the full, despite its many technical attractions.

The questions which followed both lectures led to discussions on continuous preparation. the desirability or otherwise of heat-setting before padding, the merits of infra-red pre-drying and several other points. A moasure of the interest in the subject of the conference lies in the fact that 160 people accepted invitations to attend (the conference had to be repeated on November 19, it being impossible to accommodate all on one day). In addition to members of the Shirley Instituto, representatives were present from the major Continental machinery and dyestuff manufacturers.

\section{BIOENERGETICS}

\begin{abstract}
A SYMPOSIUM on "Bioenergetics" was held at the University of Western Ontario, London, Canada, during October 15-16 under the auspices of the Biochemistry Division of the Chemical Institute of Canada. The pepers dealt, in three successive half-day sessions, with onergy transformations in the plant, microbial, and animal kingdoms. Interest in the symposium was evident from the attendance: 225 scientists wore present from places as far away as Halifax, Edmonton and California.

One of the highlights of the meeting was the afterdinner speech by Dr. R. Y. Stanier (University of California) on comparative aspects of the cytological structures involved in energy transformations. Most aerobic bacteria possess no recognizablo intracellular membrano components comparable with mitochondria. While it is possible to isolate fragments (presumably derived from outer cytoplasmic membranes) which contain oxidative enzymes, it is probably correct to view the whole bacterial cell as the smallest respiratory unit. The forms of photosynthetic structures present great variety in procaryotic cells. The chromatophores of the purple bacteria resemble the internal lamellæ seen in chloroplasts of higher forms. The lamellæ may appear as intrusions of the cytoplasmic membrane, as vesicular elements in the cytoplasm, or as transitions between the two forms. These primitive structural analogues of the chloroplast may be interpreted as early experiments on the path to evolution of the discrete. membrane-contained organelles of present-day higher organisms.

Mechanisms and intermediates of the phosphorylation reactions associated with photosynthesis were explored by Dr. D. I. Arnon (University of California) and Dr. A. T. Jagendorf (Johns Hopkins University). Central to these
\end{abstract}

and subsequent discussions on photosynthesis was the role of forredoxin, a low-molecular-weight protein containing stoichiometric proportions of non-hæm iron and sulphide, and possessing a redox potential at physiological $p H$ in the neighbourhood of that for the hydrogen electrode. One of the more interesting functions of this strongly reducing electron carrier is its ability to promote net synthesis of pyruvic acid from acetyl coenzyme $\mathrm{A}$ and $\mathrm{CO}_{2}$, a reaction of especial significance to Chromatium where the primary products of photosynthesis are amino acids. The photoreduction of ferredoxin by activated chlorophyll appears to be a primary reaction in photosynthesis leading to generation of high-energy phosphate compounds, the production of reduced pyridine nucleotides for $\mathrm{CO}_{2}$-fixation, and the evolution of molecular oxygen. By alternating light and dark periods of exposure of isolated chloroplasts it is possible to demonstrate formation in the light of a high-energy compound with a short half-life which is capable of later transferring its energy equivalents to ATP in the dark. The nature of the intermediate is not estab. lished as yet, but its formation is associated with structural changes in the chloroplast and the uptake of hydrogen ions. Dr. Jagendorf provided some illuminating specula. tions concerning the relationship of these events to the known contractile changes of mitochondria and the anisotropic membrane ATPase theory of Mitchell.

The primary event of photosynthesis, the quantumtrapping, charge-separating mechanism which leads ultimately to the splitting of water into molecular oxygen and reducing equivalents of hydrogen, was described by Dr. N. E. Good (Michigan State University) and Dr. B. Kok (Research Institute for Advanced Studies, Baltimore). The process appears to involve an aggregate of 